\title{
Erratum to: Botulinum toxin and rehabilitation treatment in inclusion body myositis for severe oropharyngeal dysphagia
}

Chiara Di Pede $^{1} \cdot$ Stefano Masiero $^{1} \cdot$ Valentina Bonsangue $^{1} \cdot$ Rosario Marchese-Ragona $^{2} \cdot$ Alessandra Del Felice ${ }^{1}$

Published online: 26 November 2016

(c) Springer-Verlag Italia 2016

Erratum to: Neurol Sci (2016) 37:1743-1745

DOI 10.1007/s10072-016-2586-x

In the original publication, the author's family and first name was wrongly identified. The name should read as Marchese-Ragona R.

The online version of the original article can be found under doi:10.1007/s10072-016-2586-x.

Alessandra Del Felice alessandra.delfelice@unipd.it

1 Department of Neuroscience, University of Padova, Via Giustiani, 3, Padua, Italy

2 Department of Ear-Nose-Throat and Head-Neck Surgery, University of Padova, Padua, Italy 